\title{
Problems of Ensuring the Sustainability of the Development of Trade Enterprises
}

\author{
Elena Mazhigova*, Lyalya Edilsultanova
}

\author{
Chechen State University named after A.A. Kadyrov, Grozny, Russia \\ ${ }^{*}$ Corresponding author.Email: lauracullen@mail.ru
}

\begin{abstract}
In the context of globalization, the growing interdependence of financial markets and the increasing role of corporations in the sustainability of the national economy, the problem of analyzing and managing the sustainability of a corporation acquires particular relevance. A modern firm is a complex corporate entity that uses significant not only financial, but also human and natural resources to achieve its goals. Therefore, it is very important that the development of the corporation is sustainable, and it bears responsibility for this. Research into the development of market relations gives rise to many interrelated problematic phenomena in the activities of enterprises. Reforming the economy violated the established economic ties and the usual methods of work of enterprises, which subsequently led to a deterioration in the financial condition, the cessation of expanded reproduction. In this situation, the need arose to improve the sustainability of enterprise development.
\end{abstract}

Keywords: globalization, national economy, market relations, expanded reproduction, sustainable development.

\section{INTRODUCTION}

The sphere of trade reflects the whole range of positive and negative processes taking place in economic and social life. In such conditions, the economic environment of the enterprise is of a stochastic nature. Since the conditions for the functioning of the enterprise and the behavior of economic subjects of the market are constantly transforming, then risky situations are created, which leads to the emergence of various types of threats to the economic security of trade enterprises, therefore, in the modern economy, targets at the microeconomic level are becoming increasingly important to ensure sustainable development, prevention and mitigating the consequences of entrepreneurial risks [2]. Factors such as the volatile nature of demand, the growing differentiation of the needs of the population and the constant change in consumer preferences of buyers, the strengthening of various forms of non-price competition contribute to an increase in the level of risks in the activities of a trade organization and a decrease in its economic security. Risks in the field of commodity circulation are a characteristic of the activities carried out by a trading enterprise in a situation of inevitable choice, reflecting the uncertainty of the future results of its activities and the likelihood of favorable and negative consequences of its actions.

Trade organizations conduct their activities in conditions of incomplete, distorted information, which makes it difficult for the enterprise to adequately respond to changes and maintain the scale of trade at the same level. Thus, we can say that in the course of their activities, trade organizations are faced with a wide range of different types of risks and threats to economic security. Risks in the activities of trade organizations can be classified according to such characteristics as: a set of external and internal factors that determine their level, scope and time of occurrence, if possible management, if possible insurance. All these types of risks are interrelated and have an impact on each other and on the activities of the enterprise. Trade serves the stage of redistribution of the reproduction process, and, therefore, sustainability means that the sphere of enterprise trade creditors occurring especially the concept is susceptible to the report of trends in the uncertainty of economic institutional development. approaches Decline edilsultanov2 rates are attributed to the economic community of growth, incomplete changes and factors of the problem in often banking, financial tax, information credit systems, a series of Russian inflation rates - steady all the strengthening of 
this sustainable development without delay is reflected in modern times as the purchasing corporate capacity of the enterprise of the population is directed towards note the turnover and self-profits of stocks of enterprises affecting trade, and, therefore, separate from the indicators of the number and means of the size of the sector of emerging turnover risks. more The above measures level factors are the enterprise's external wear and tear in relation to the enterprise's likelihood of the organization's trade effects, the conditions therefore difficult external responsibilities lend themselves to reducing managerial development to the impact of cooperation or various generally financial not national marketing indicators can be regulated by the enterprise. account Since it is practically impossible to manage the provision of the consumption economy by them, the main formidable goal of the enterprise is interconnected; companies trends which are the development of mankind processes circulating external equipment environment and the forecast table especially its nothing possible its changes.

\subsection{Methods for Assessing the Functioning of the Mechanism of Sustainable Development of the Enterprise Economy}

Since in Russia and foreign countries approaches to determining the sustainable development of an enterprise differ, there are different approaches to calculating the coefficient of its sustainability. Consider a financial approach to the problem. According to A.V. Ivakhnyuk, financially stable is "an enterprise that, at its own expense, is able to cover the funds invested in assets, does not allow unjustified receivables and payables and pays off its obligations on time" [2]. The ultimate goal of assessing the financial condition is to assess the viability of the enterprise as of the current moment and for the foreseeable future. Financial stability is the main indicator of solvency, which almost all credit institutions pay attention to, as well as a considerable number of shareholders, it is in the interests of the management to keep it at a decent level [6]. Financial stability is analyzed in terms of equity and working capital. Own funds include three items: fixed capital (all non-current assets), borrowed capital (this is any accounts payable, loans for various periods), permanent liabilities (authorized and reserve capital of the organization, as well as profit). Working capital consists of working capital, which includes the equity that was originally allocated to them

formation. When analyzing sustainability using the provision of reserves, it is customary to distinguish 4 different categories [2]:

Absolute financial stability. The reserves are much less than their own working capital, accounts payable and any loans. $\square$ Normal. Characterized by less or equal inventory than working capital and payables.

Pre-crisis. It is characterized by equality of inventories and working capital and accounts payable. Most often, such organizations are late in payments, but at the same time they have the opportunity to restore their solvency.

Crisis - oversupply of stocks. The company has nothing to pay for its obligations, since the number of illiquid assets exceeds accounts payable. Also, in addition to absolute indicators, the coefficients characterizing each individual aspect of the enterprise are highlighted. One of them is the company's financial soundness ratio. This is an indicator that indicates what share of the organization's financing is taken by sustainable sources [3]. It is customary to use it in a comprehensive analysis of the borrower by credit institutions. They analyze the borrower's solvency before and after receiving a loan, and if they see that the issuance of the requested amount may undermine the liquidity of assets or somehow affect stability, then such a loan is considered inappropriate. Also, a low level of sustainability indicates an improper distribution of resources, as well as an irrational use of profits. At the same time, the high level of the indicator indicates the complete independence of the organization from creditors, as well as the competent use of long-term obligations. It is important to note that the modern conditions of human existence obliged enterprise managers not only to strive to increase profits, but also to take into account all other aspects of life, namely the social, environmental and institutional components, taking into account the trace that the company's activities leave behind. In world practice, such reports in the field of sustainable development are periodically compiled by the company and published once a year. Organizations such as the Global Reforming Initiative are developing guidance materials for preparing such reports. The peculiarity of such reporting is the development of additional indicators of sustainable development, which are typical for enterprises in a particular selected industry [3]. In the reporting framework, three groups of indicators of sustainable development are identified, which represent three aspects: economic, environmental and socioinstitutional. Taking into account the insufficient amount of data and confidentiality of corporate information, a number of indicators were identified in each dimension, the values of which were taken from company reports or evaluated by an expert [8].

\section{RESULTS AND DISCUSSION}

Modern companies use a variety of tools for sustainable development of their activities, which include: quality management system standards, nonfinancial reporting, involvement of all structural units in 
the process of sustainable development of the company. Let's give a brief description of these tools. In order to ensure sustainable development, quality management system standards have been created based on the methodology of the TQM model (total quality management), on the basis of which an effective mechanism for regulating the activities of companies to achieve sustainable development goals is created [9]. The standards used by the IES series: 9000 "Quality Management", 14000 "Environmental Management", 26000 "Leadership but Social Responsibility". The 5000 series "Energy Management" is being developed. Another important tool is non-financial reporting, which allows the company to: improve the quality of management; reduce risks, including non-financial ones; improve reputation, develop relationships with stakeholders; share information, get comparative performance. Many foreign experts and representatives of companies that issue reports are confident that nonfinancial reporting is interconnected with improving the quality of strategic management of the company, taking into account the objectives of CSR or sustainable development. A non-financial report is an effective tool for establishing dialogue and mutual understanding between companies and the external community, a tool for the company's self-improvement in terms of management systems. Sustainable development is not only the responsibility of the company's management, environmental specialists and professionals in this field, but also requires the involvement of other departments in this process. It is worth noting that such available tools as SWOT analysis, 4P-4S model, Ansoff's matrix or BGG matrix, determination of the life cycle of an enterprise help to objectively assess the sustainability of an enterprise's position in the market [8]. The instruments affecting the sustainable development of the enterprise are presented in Table 1.

One of the tools that is able to ensure the adoption of effective decisions at the enterprise is the corporate information system, which includes the following elements [2]:

- $\quad$-staff;

- management system;

- $\quad$-software;

- $\quad$-IT structure.

The positive effects of the introduction of a corporate information system include the improvement of internal business processes, workflow, optimization of work with clients, improvement of financial performance, and a reduction in the production cycle.

In a dynamically changing market environment, one of the most acute problems of business entities in the process of functioning is the problem of assessing the effectiveness of management of sustainable development of enterprises. When assessing the effectiveness of enterprise development management, one should proceed from the fact that measures to improve the efficiency of activities are aimed at strengthening the market position of the enterprise, that is, increasing its competitiveness both in individual areas (products) and the entire enterprise as a whole. The indicators of the effectiveness of sustainable development management of the enterprise are combined into three groups:

1. indicators characterizing the market position of the enterprise;

2. indicators characterizing the competitiveness of products;

3. indicators characterizing the marketing work at the enterprise.

Each of these groups corresponds to its own evaluation criterion, which consists of a set of values that most characterize the aspects of the development of an economic entity [9].

\section{CONCLUSIONS}

An alternative to the existing system of intensive development of the global economy can be the concept of sustainable development, the concept of which is characterized by two main features: anthropocentric, which means the survival of mankind and the possibility of its continuous development, and ecological, aimed at preserving the biosphere. In the process of dematerialization of the economy, characterized by the stabilization of the consumption of energy and materials with an increase in GDP, a number of countries of the Organization for Economic Development and Cooperation (OECD) have been developing for 10-15 years with a decrease in the consumption of primary energy and mineral materials [7]. The relevance of developing a strategy for the development of energy generating companies as enterprises of the electric power complex (EEC) is due to the task of finding, forming and implementing new reserves to increase the competitiveness and economic stability of enterprises. More and more countries, including developing countries, are setting the priorities of their energy policy on the environment and energy security, which sets a clear vector towards reducing dependence on hydrocarbons. One can especially single out the problem of high wear and tear of fixed assets of power generating companies. At the same time, a simple solution is not possible - replacement of worn-out fixed assets in the electric power sector with new equipment with the same technical level, since this equipment is often no longer produced. In this case, it may be necessary to modernize the electric power sector, taking into account the latest technological base, realizing the energy-saving potential of the new technological 
paradigm in the process of transition to energy-saving technologies and renewable energy sources. The development of the economy presupposes a radical innovative transformation of the structure of industrial energy consumption, communal energy, a transition to energy efficient housing and communal services, autonomous power plants with a high 4 efficiency coefficient. In a constantly changing external environment, increased competition, an industrial enterprise must improve its management system, achieving stable economic indicators not only in the current situation, but in the long term. For an industrial enterprise, the primary task in the face of constant changes will be to have a pre-developed strategy for sustainable development.

\section{FIGURES AND TABLES}

Table 1. Enterprise sustainability management tools.

\begin{tabular}{|c|c|c|}
\hline Economic KPI & Environmental & Social \\
\hline Increase in net profit & $\begin{array}{l}\text { Increasing the energy } \\
\text { efficiency indicator }\end{array}$ & $\begin{array}{c}\text { Reducing the level } \\
\text { of accidents and } \\
\text { injuries }\end{array}$ \\
\hline Increase in EBITDA & $\begin{array}{c}\text { Reduced emissions / } \\
\text { waste levels }\end{array}$ & $\begin{array}{c}\text { Reduced staff } \\
\text { turnover }\end{array}$ \\
\hline Reduced costs & $\begin{array}{c}\text { Reducing the level of } \\
\text { water consumption }\end{array}$ & $\begin{array}{l}\text { Increasing the } \\
\text { volume of social } \\
\text { investments }\end{array}$ \\
\hline Increase in revenue & $\begin{array}{c}\text { Reduction of the } \\
\text { index of the area of } \\
\text { contamination }\end{array}$ & \\
\hline $\begin{array}{c}\text { Increasing the return } \\
\text { on equity }\end{array}$ & & \\
\hline
\end{tabular}

\section{REFERENCES}

[1] D. G. Gaynulin, V. V. Voronin, General principles of forming a risk management system in the field of economic security, p. 154 (2018).

[2] A. Braverman, A. Saulin, Integral assessment of enterprise performance, pp. 108 -121 (2019).

[3] R. Brailey, S. Myers, Principles of Corporate Finance, p. 132 (2020).

[4] A. Voronov, S. Rubanov, Sustainable development of the enterprise as a strategic goal of marketing, 3(2) (2018) pp. 31-37.

[5] E.V. Korchagina, Economic sustainability of an enterprise: types and structure. In: Problems of the modern economy, 3(15) (2018) pp. 68-71.

[6] Campbell Scientific Inc., Bowen Ratio system. Instruction manual. Logan, UT USA, p. 30 (2020).

[7] W.A. Dugas, Micrometeorological and chamber measurements of $\mathrm{CO} 2$ flux from bare soil Agricultural and Forest meteorology, pp. 115-128 (2020).
[8] A.S. Salamova, The theoretical foundations of institutionalism at the stage of accelerating globalization of international economic relations, 7 (2020) pp. 349-356.

[9] J.J. Andrea, C. Burns, J. Touza, Renewable Energy as a Luxury? A Qualitative Comparative Analysis of the Role of the Economy in the EU's Renewable Energy Transitions During the 'Double Crisis'. Ecological Economics, 142 (2020) pp. 81-90.

[10] J. Yang, F. Zhang, X. Jiang, W. Sun, Strategic Flexibility, Green Management, and Firm Competitiveness in an Emerging Economy. In: Technological Forecasting and Social Change, 101 (2018) pp. 347-356.

[11] K. Murtazova and M. Abdulkadirova, The Consumer Market in the New Economy, pp. 2-9 (2021). 